\title{
Attenuation of Myocardial Fibrosis with Curcumin Is Mediated by Modulating Expression of Angiotensin II ATI/AT2 Receptors and ACE2 in Rats [Corrigendum]
}

\section{Pang X, Zhang L, Bai F, et al. Drug Des Devel Ther. 2015;9:6043-6054.}

The authors have advised there is an error in the Western blot bands shown in Figure 6 on page 6050, pSmad 2 at 2 weeks.

Each band shown in Figure 6 represents one animal, and six or seven animals were used for each group. The statistical difference was calculated from the protein analysis using every animal tissue sample. Once the overall group statistical difference was found, three bands were chosen

to represent the difference more closely between the control (Con) and curcumin (Cur) groups. The authors acknowledge the error in using the same bands in lanes two and three to show pSmad 2 at 2 weeks in the Con group. The data have been newly and independently validated from additional samples, and the results have demonstrated symmetrical expression of pSmad 2 in the Con group as shown in the correct Figure 6 below.

The authors apologize for this error.
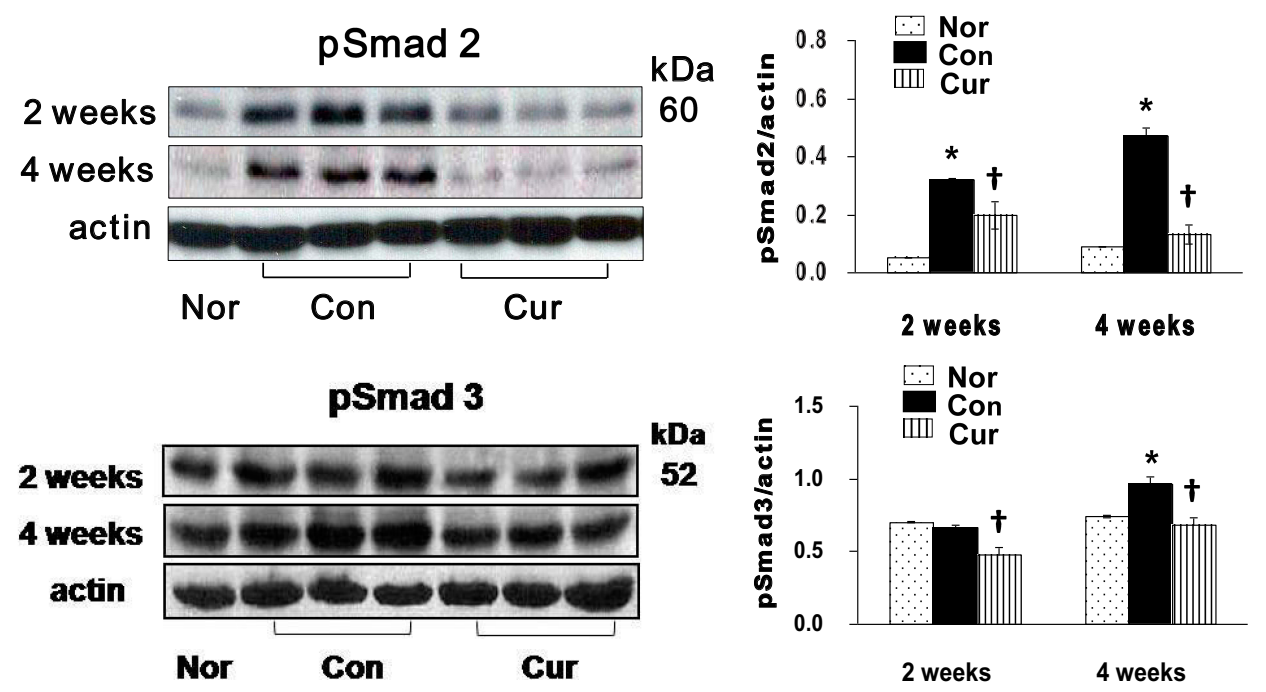

Figure 6 Phosphorylation of Smad2/3 during Ang II infusion. Ang II caused a significant increase in phospho-Smad2/3 levels at week 4, as normalized by actin for each band, which were significantly inhibited by curcumin.

Notes: Values are mean $\pm \mathrm{SEM} ; \mathrm{n}=6$ for each group. $* P<0.05$ Ang II infusion (Con) vs sham (Nor); ${ }^{\dagger} P<0.05$ curcumin (Cur) vs Con.

Abbreviations: pSmad, phosphorylated Smad; Ang II, angiotensin II; Con, control Ang II infusion treatment group; Nor, normal sham curcumin treatment group; Cur, curcumin plus Ang II treatment group; $n$, number of rats; SEM, standard error of the mean.

\section{Publish your work in this journal}

Drug Design, Development and Therapy is an international, peerreviewed open-access journal that spans the spectrum of drug design and development through to clinical applications. Clinical outcomes, patient safety, and programs for the development and effective, safe, and sustained use of medicines are a feature of the journal, which has also

been accepted for indexing on PubMed Central. The manuscript management system is completely online and includes a very quick and fair peer-review system, which is all easy to use. Visit http://www. dovepress.com/testimonials.php to read real quotes from published authors. 